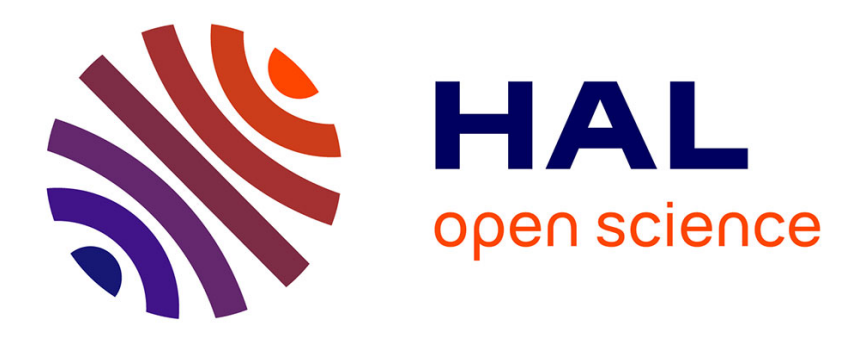

\title{
Deposition of Boron Containing Coatings Using MO-PACVD Process to Protect Aluminium Casting Tools
}

K.-T. Rie, A. Gebauer, C. Pfohl

\section{- To cite this version:}

K.-T. Rie, A. Gebauer, C. Pfohl. Deposition of Boron Containing Coatings Using MO-PACVD Process to Protect Aluminium Casting Tools. Journal de Physique IV Proceedings, 1995, 05 (C5), pp.C5-637C5-645. 10.1051/jphyscol:1995576 . jpa-00253938

\section{HAL Id: jpa-00253938 https://hal.science/jpa-00253938}

Submitted on 1 Jan 1995

HAL is a multi-disciplinary open access archive for the deposit and dissemination of scientific research documents, whether they are published or not. The documents may come from teaching and research institutions in France or abroad, or from public or private research centers.
L'archive ouverte pluridisciplinaire HAL, est destinée au dépôt et à la diffusion de documents scientifiques de niveau recherche, publiés ou non, émanant des établissements d'enseignement et de recherche français ou étrangers, des laboratoires publics ou privés. 


\title{
Deposition of Boron Containing Coatings Using MO-PACVD Process to Protect Aluminium Casting Tools
}

K.-T. Rie, A. Gebauer* and C. Pfohl

Institut für Oberflächentechnik und Plasmatechnische Werkstoffentwicklung, TU Braunschweig, Bienroder Weg 53, 38108 Braunschweig, Germany

* Fraunhofer-Institut für Schicht- und Oberflächentechnik, Bienroder Weg 54E, 38108 Braunschweig, Germany

\begin{abstract}
In this paper the synthesis of $(B, C, N), \operatorname{Zr}(B, C)$ and $\operatorname{Zr}(B, C, N)$ layers is investigated by means of DC pulsed plasma assisted CVD using organic compounds as precursors. The process parameters such as coating temperature, gas pressure, gas mixture, plasma parameters are varied to deposit functional coatings on hot-work steel used in the aluminium die casting industry. One of the objectives is to realize a layer type which withstands the severe service conditions in aluminium die casting. Another objective is to lower the coating temperature. The layers have been studied by light- and scanning electron microscopy (SEM). The properties of the deposited layers are determined by various analytical methods such as WDS-analysis for the chemical composition and X-ray diffraction (XRD) for the morphology. The hardness and adhesion of the layers were measured to determine the mechanical properties. The adhesion to liquid aluminium is investigated and compared to TiN layers deposited with $\mathrm{TiCl}_{4}$ as precursor.
\end{abstract}

\section{INTRODUCTION}

The application of hard coatings in many industrial fields is nowadays state of art. Examples are cutting procedures and metal forming in manufacturing industry. In aluminium casting processes the dies and forms have to withstand the severe loading, such as abrasive wear, adhesive wear, corrosion by molten metals, hydrogen attack, thermal shock and thermal fatigue. Investigations of particular aspects in the past showed the success of coated or surface treated casting tools [1]. Primary concern is the development of a layer or layer types which satisfy all of the described wear mechanisms. These layers must be a very good compromise to fulfil the requirements in casting processes

A few coating processes such as PVD and CVD methods are competitive in the domain of thin film 
technology. CVD methods have been proved to be an excellent process for hard coatings and offer the advantage of uniform coating even for complicated geometries. However, conventional CVD of thin coatings requires high deposition temperature and therefore restricts the application. By the development of plasma assisted CVD the coating temperatures of thermal CVD can be reduced to $600-500^{\circ} \mathrm{C}$ and a homogeneous coating of complicated parts is readily possible. Due to the higher reactivity of metalloorganic compounds [2] the deposition temperature can be lowered using these compounds as precursors. The harmful effect of chlorine on layers and on PACVD equipment can be avoided by using nonchlorinated metallo-organic compounds (MOC) as precursors. MOCVD offers the advantages of mild process conditions, control over microstructure and composition, and high deposition rates $[3,4]$.

\section{CVD PRECURSORS}

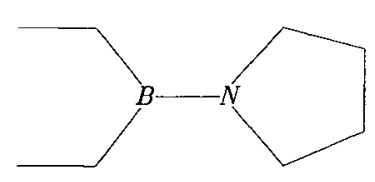

(a)



(b)

Figure 1: $\quad$ Structure of used organometallics: $\mathrm{C}_{8} \mathrm{H}_{18} \mathrm{BN}(\mathrm{a}), \mathrm{CpZr}\left(\mathrm{BH}_{4}\right)_{3}$ (b)

Table 1: Chemical composition, state of aggregation of organometallics and in PACVD process deposited layers (Cp: cyclopentadienyl-)

\begin{tabular}{|c|c|c|c|}
\hline precursor & $\begin{array}{c}\text { state of } \\
\text { aggregation }\end{array}$ & $\begin{array}{c}\text { boiling point } /{ }^{\circ} \mathrm{C}, \\
\text { pressure } / \mathrm{Pa}\end{array}$ & deposited layer \\
\hline $\mathrm{CpZr}\left(\mathrm{BH}_{4}\right)_{3}$ & solid & sublimes $35-40 / 13,3$ & $\mathrm{Zr}(\mathrm{C}, \mathrm{N}), \mathrm{Zr}(\mathrm{B}, \mathrm{C}, \mathrm{N})$ \\
\hline $\mathrm{C}_{8} \mathrm{H}_{18} \mathrm{BN}$ & liquid & $70 / 1800$ & $(\mathrm{~B}, \mathrm{C}, \mathrm{N})$ \\
\hline
\end{tabular}

To deposit boron containing coatings two organometallics as precursors are used: ( $\eta$ cyclopentadienyl)zirconiumtristetrahydroborate $\mathrm{CpZr}\left(\mathrm{BH}_{4}\right)_{3}$ and $\left(\mathrm{N}\right.$-pyrrolidino)diethylborane $\mathrm{C}_{8} \mathrm{H}_{18} \mathrm{BN}$. The synthesis of these compounds is already described $[5,6]$. Figure 1 shows the structure of the molecules and table 1 the chemical composition, some volatility data and deposited layers in PACVD process. Since all of these substances are sensitive to oxygen and moisture, special precautions in handling and deposition are necessary. Complete vapour pressure diagrams do not exist for these compounds. For comparison the conventional halogenated precursor $\mathrm{TiCl}_{4}$ was used in some experiments. 


\section{APPARATUS}



Figure 2: $\quad$ Experimental set-up of PACVD and OES equipment

Figure 2 shows a schematic layout of the equipment which is described in detail elsewhere [7]. The PACVD equipment consists of a steel reactor with an additional heating, a process gas control system for the pure gases $\mathrm{Ar}, \mathrm{H}_{2}, \mathrm{~N}_{2}$, a metal donor evaporator with carrier gas, a pulsed power supply, a process control system and the vacuum pump set with pressure control. The liquid or solid metal donor used is evaporated or sublimed and led into the reaction chamber by the carrier gas. The power supply generates pulsed DC up to $900 \mathrm{~V}$ and $50 \mathrm{kHz}$. The plasma exists between the cathodic substrates and the anodic reactor wall. An optical emission spectroscopy (OES) device is integrated for in situ plasma diagnostics. The emitted spectra of the discharge are recorded using a monochromator with a diode array (optical multichannel analyzer, OMA) and a photomultiplier tube (PMT).

\section{EXPERIMENTAL DETAILS}

The objective of the study is to investigate the formation of boron containing coatings by PACVD using metallo-organic compounds as precursors to protect aluminium casting tools. Typical process parameters are listed in table 2. The treatment gas was mainly composed of $\mathrm{H}_{2}$ and $\mathrm{N}_{2} \cdot \mathrm{H}_{2}$ was the carrier gas. Flat samples were used for the tests. The layers were produced on tempering steel $(1.1181, \mathrm{Ck} 35)$ and hot-work steel (1.2344, X $40 \mathrm{CrMoV} 5$ 1) as used in aluminium die casting. The hot-work steel substrates were hardened by heat treatment to reduce the hardness difference between substrate and layer. The coating temperature should be less than the tempering temperature to avoid any post heat treatment. 
determined by calotte grindings and fracture surface. The layer thickness was in the range from 0.5 to $12 \mu \mathrm{m}$. Figure 3 shows the surface topography of a $\operatorname{Zr}(B, C, N)$ layer. The layer is smooth and presents the typical appearance as found for PACVD coatings [8]. Figure 4 demonstrates an example of a fracture cross-section with a very compact structure. The fracture cross-sections confirm the dense and fine grained structure without columnar crystals which is important for the layer properties such as hardness or corrosion resistance.



Figure 4: $\quad$ Fracture surface of a $\mathrm{Zr}(\mathrm{B}, \mathrm{C}, \mathrm{N})$ layer on 1.2344 , precursor $\mathrm{CpZr}\left(\mathrm{BH}_{4}\right)_{3}, 500 \mathrm{~V}, 100 \mathrm{~Pa}$, $430^{\circ} \mathrm{C}$, gas $\mathrm{H}_{2} / \mathrm{N}_{2}, 2 \mathrm{~h}$

\subsection{Chemical element analysis and X-ray diffraction}

The chemical analysis of the layers proves that the layers are composed of carbon, nitrogen, boron, small amounts of oxygen and zirconium in case of the precursor $\mathrm{CpZr}\left(\mathrm{BH}_{4}\right)_{3}$. Oxygen incorporation probably results from traces of $\mathrm{O}_{2}$ and/or $\mathrm{H}_{2} \mathrm{O}$ in the carrier gas. Fig. 5 shows the relation between discharge voltage and element concentration of $\mathrm{Zr}(\mathrm{B}, \mathrm{C}, \mathrm{N})$ layers. The $\mathrm{Zr}$ content is nearly constant. $\mathrm{B}$, $\mathrm{N}$ increase and $\mathrm{C}$ decreases with increasing voltage. Similar tendencies were observed for gas pressure and substrate temperature.

In X-ray diffraction analysis there are only low intensity broad peaks of the boron containing phase additionally to the peaks of $\alpha-\mathrm{Fe}$ in the base material: This indicates a quasi amorphous type of layer. Very fine grained structure as well as high internal stress results in broadened peaks. 




Figure 5: Element concentration vs. discharge voltage, $\mathrm{Zr}(\mathrm{B}, \mathrm{C}, \mathrm{N})$ layer, precursor $\mathrm{CpZr}\left(\mathrm{BH}_{4}\right)_{3}$, $100 \mathrm{~Pa}, 330^{\circ} \mathrm{C}$, gas $\mathrm{H}_{2} / \mathrm{N}_{2}, 2 \mathrm{~h}$

\subsection{Mechanical and technological properties}

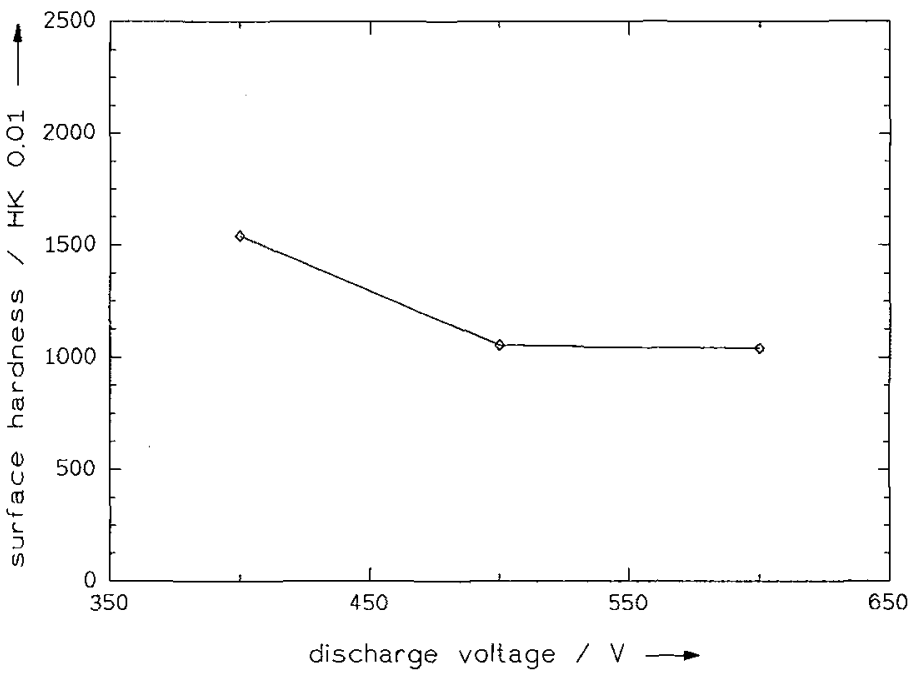

Figure 6: Hardness vs. discharge voltage, $\mathrm{Zr}(\mathrm{B}, \mathrm{C}, \mathrm{N})$ layer, precursor $\mathrm{CpZr}\left(\mathrm{BH}_{4}\right)_{3}, 100 \mathrm{~Pa}, 330^{\circ} \mathrm{C}$, gas $\mathrm{H}_{2} / \mathrm{N}_{2}, 2 \mathrm{~h}$

The mechanical and technological properties such as hardness and adhesion are influenced by the process parameters as deposition temperature, gas pressure and plasma parameters. For example figure 6 demonstrates the decreasing hardness with increasing discharge voltage belonging to the decreasing $\mathrm{C}$ 
content (fig. 5). The hardness of the carbide is higher than that of the corresponding nitride. Same results were obtained for the other parameters with decreasing carbide content. In this study hardness values of about $1100-1600 \mathrm{HK} 0.01$ for both layer types were obtained. Scratch tests of $\operatorname{Zr}(B, C, N)$ showed critical loads of up to $60 \mathrm{~N}$ by light-optical microscopy interpretation of the scratch-track. (B,C,N) layers deposited at $250^{\circ} \mathrm{C}$ reached critical loads up to $40 \mathrm{~N}$.

\subsection{Optical emission spectroscopy}

Here, optical emission spectroscopy (OES) was Table 3: $\quad$ Spectral lines of detected species used as an in situ diagnostic method for qualitative analysis of species. OES is a powerful tool for controlling the coating process and for optimizing both the layer properties and the coating process. Table 3 gives some spectral lines of metals and molecular fragments which occur in the discharge

\begin{tabular}{|c|c|c|c|}
\hline species & \multicolumn{3}{|c|}{ wavelength / $\mathrm{nm}$} \\
\hline $\mathrm{Zr}^{+}$ & 339.2 & 343.8 & 349.6 \\
\hline $\mathrm{N}_{2}{ }^{+}$ & 391.4 & 427.8 & \\
\hline $\mathrm{B}_{2}$ & 327.3 & 327.9 & \\
\hline $\mathrm{CH}$ & 431.4 & & \\
\hline
\end{tabular}
during $\mathrm{Zr}(\mathrm{B}, \mathrm{C}, \mathrm{N})$ coating.

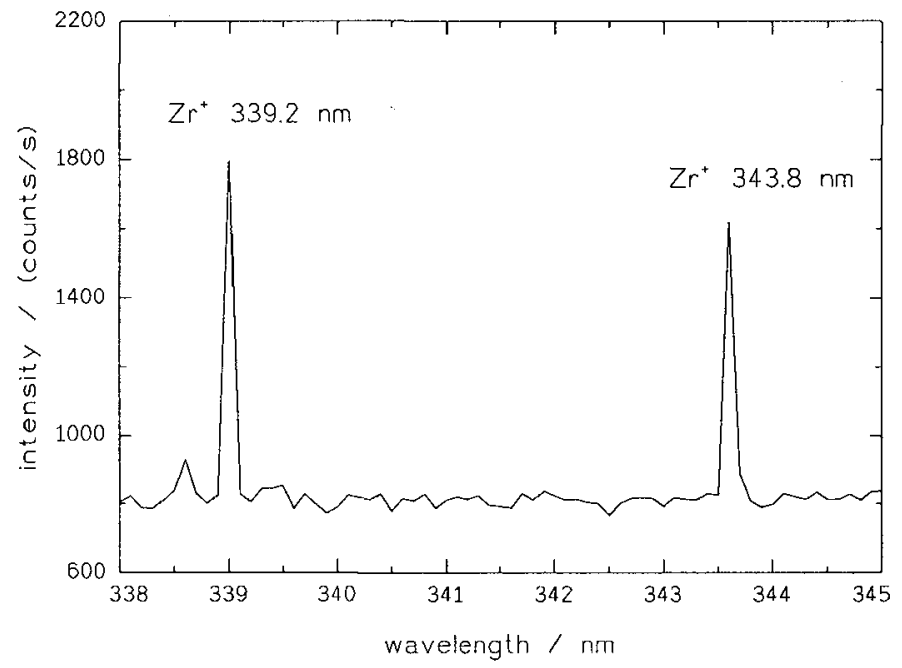

Figure 7: Optical emission spectrum, deposition of a $\mathrm{Zr}(\mathrm{B}, \mathrm{C}, \mathrm{N})$ layer, precursor $\mathrm{CpZr}\left(\mathrm{BH}_{4}\right)_{3}, 100$ $\mathrm{Pa}, 330^{\circ} \mathrm{C}, 500 \mathrm{~V}$, gas $\mathrm{H}_{2} / \mathrm{N}_{2}, 2 \mathrm{~h}$

Figure 7 shows an emission spectrum of a coating process at $330^{\circ} \mathrm{C}, 100 \mathrm{~Pa}$ and $500 \mathrm{~V}$. The lines at $339.2 \mathrm{~nm}$ and $343.8 \mathrm{~nm}$ wavelength indicate the occurrence of zirconium ions in the plasma for 
deposition of a $\operatorname{Zr}(B, C, N)$ layer. Compounds of $\mathrm{Zr}$ and $\mathrm{C}, \mathrm{N}$ or $\mathrm{B}$ could not be detected in the gas phase by OES. Fragments $(\mathrm{CH})$ of the precursor molecule appear in the discharge. Thus the precursor molecules are destroyed in the discharge by the ion bombardment.

\subsection{Dip-test in molten aluminium}

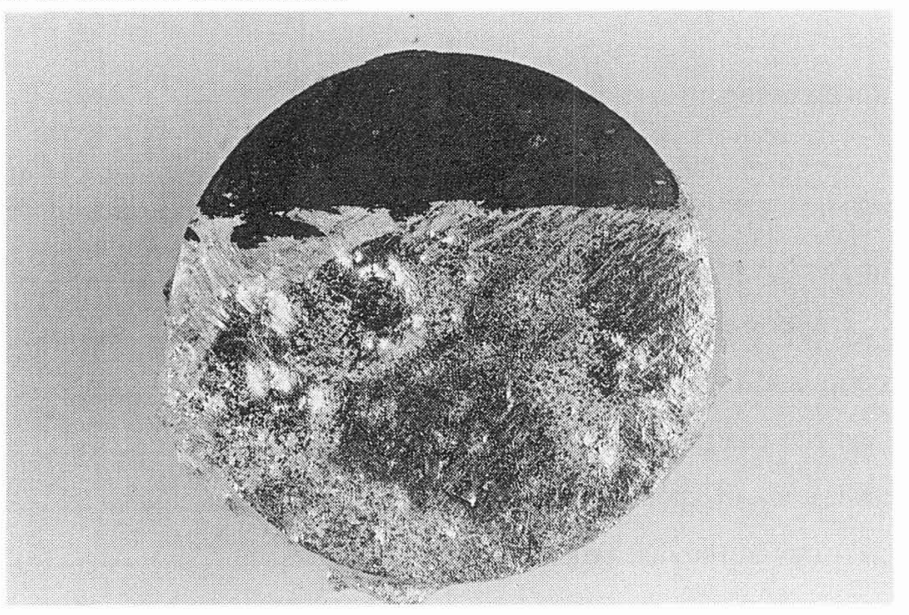

Figure 8: $\quad(B, C, N)$ coated sample with rest of aluminium

Samples were dipped in molten aluminium heated up to $700^{\circ} \mathrm{C}$ as indicator for the corrosion resistance and adhesion to molten aluminium. After dipping in the molten aluminium rest of aluminium could be detected on the surface of the $(B, C, N)$ and $\mathrm{Zr}(B, C, N)$ layers (Figure 8). Aluminium is adhesive to these layer types in this test. After removing the aluminium film no chemical reaction between aluminium and layer material was noticed. TiN layers with $\mathrm{TiCl}_{4}$ as precursor showed the same behaviour. After six hours dipping in molten aluminium the corrosion attack to the layers was negligible. In the long time tests corrosion starts at layers defects as cracks where the aluminium diffuses into the steel substrate. The TiN layer material itself remained undamaged. The corrosion resistant layers must be pinhole free and without any crack. Further tests have to explain the corrosion and adhesion mechanisms.

\section{Conclusions}

This work has illustrated the usefulness of organic compounds for deposition of boron containing layers in PACVD process, for the following reasons.

1) The deposition of $\mathrm{Zr}(\mathrm{B}, \mathrm{C}, \mathrm{N}), \mathrm{Zr}(\mathrm{B}, \mathrm{C})$ and $(\mathrm{B}, \mathrm{C}, \mathrm{N})$ layers can be carried out below the tempering temperature of the hot-work steel.

2) The layers have good adhesion to the substrate. 
3) In situ process control can be performed by OES. In particular the detection of metal species and organic fragments in the discharge allows a process optimization by correlation of layer properties and results of OES [9].

4) Concerning to the corrosion resistance of the layers first dip-tests in molten aluminium show promising results.

\section{Acknowledgments}

We are grateful to the Deutsche Forschungsgemeinschaft (DFG) for the support of this work.

\section{$\underline{\text { References }}$}

[1] Kornmann M. and Funk R., Aluminium 53 (1977) 249-252.

[2] Girolami G. S., Jensen J. A., Gozum J. E. and Pollina D. M., Mater. Res. Soc. Symp. Proc. (Better Ceram. Chem. 3) 121 (1988) 429 - 438.

[3] Barron A. R. , The Strem Chemiker, XIII (1990) 1-9.

[4] Gozum J. E., Pollina D. M., Jensen J. A. and Girolami G. S., J. Am. Chem. Soc., 110 (1988) $2688-2689$.

[5] Rie K.-T., Gebauer A., Wöhle J., Erker G., Sarter C. and Fritze C., Mat.-wiss. u. Werkstofftech. 24 (1993) 353-355.

[6] Rie K.-T., Gebauer A., Wöhle J., Erker G., Mohr R. and Sarter C., Mat.-wiss. u. Werkstofftech. 25 (1994) 431-434.

[7] Gebauer A., VDI-Fortschrittberichte 5, No. 344, VDI-Verlag GmbH, Düsseldorf (Germany), 1994,57 - 60 .

[8] Rie K.-T., Gebauer A., Wöhle J., Surface and Coatings Technology, 59 (1993) 202 - 206

[9] Rie K.-T., Gebauer A., Wöhle J., Surface and Coatings Technology, 60 (1993) 385 - 388 